\title{
Does a firm's political connection to government have economic value?
}

\begin{abstract}
This paper reports new findings about differential impacts political events have on share prices of firms connected to government in power compared to firms with no political connections. Political connection has been alleged as valuable in popular press in this midincome economy studied, so it is worth an investigation. Significant share price increases of $4 \%$ or more abnormal returns accrue to connected firms relative to unconnected firms when identical political events occur. The impact is very pronounced during a severe economic crisis, when the stakes were high about an incumbent government being re-elected. Our finding of higher value of politically connected firms is due to the expected value of preferential treatments, preference in project selections and access to state benefits. Thus, share prices of politically connected firms react with greater impacts than non-politically connected firms to announcements of identical political events.
\end{abstract}

Keyword: Political control; Event study; Patronage; Ownership and control; Rent seeking 